\title{
Re-visiting Orientalism in Antony and Cleopatra
}

\section{Nastaran Fadaei Heidari}

Department of English Language and Literature University, Istanbul Aydin University

Email: nastaranfadaeiheidari@gmail.com

\begin{abstract}
Despite the fact that we have been presented with a fixed opposition between the Occident and the Orient, the dynamics of Said's Orientalism are not valid within the context of the sixteenth and seventeenth centuries when England was not yet an Empire. In Antony and Cleopatra, gender hierarchy and racial hierarchy are intertwined and are embedded in the love relationship between Antony and Cleopatra. Throughout this period, the Ottoman Empire was the dominant superpower. Europe could not establish any response against this Islamic enemy. In this essay, I argue that, overturning the imperial and gender hierarchies, invokes European anxieties with respect to the rising power of Islam. Efforts against feminization, 'turning Turk' and 'going native' of Englishmen proves the fear of the authorities from the dominating East.
\end{abstract}

Keywords-Orientalism, Racial Hierarchy, Imperial Hierarchy, going native, feminization

As opposed to Said's argument in Orientalism that the East is depicted as inferior (associated with irrationality and savagery) in order for the West to subjugate and colonize it, the exotic, cunning power and domination of Cleopatra over a Roman ruler is regarded as posing a threat to the Empire and its patriarchal order. This chapter will argue that Antony's attraction to Cleopatra is a way of expressing Shakespeare's contemporary English fears about the removal of identity and masculinity of the English by the East. It will also argue that Antony's flaws are partly and greatly due to going native, that is, leaving his Roman way of life by settling in Egypt and adopting their lifestyle, becoming effeminised by being mesmerised in the exotic East as represented by Cleopatra and consequently betraying the Roman Empire and values it stands for. This fear of the English going Turk or native comes from the anxiety and fear of a potential domination of the East at the time of strong Ottoman Empire. Moreover, it will be argued that Cleopatra does not submit to Rome, a characteristic that enhances English fear fantasising about the feminization of Englishmen when they encounter sexual and lustful Eastern women. This is reinforced as Cleopatra, together with her surroundings, is depicted as triggering unpredictability, exoticism, seduction, mystery and cunningness, especially when compared to other Shakespeare's female heroines. As opposed to a stereotypical representation of women as the body - obedient and submissive driven by inherent instincts - she exemplifies an intentional agency who exercises the intellect by planning all the way through the play and finally designing her own death. Finally, it will be argued that gender and power hierarchies are overturned in the play which lays bare the West's fear that their identity could be exchanged that they might go native and lose their identity in their encounter with the Turks.

Antony and Cleopatra is a tragedy by William Shakespeare, which was written in 1606-7. The play was first performed by the King's Men, either at the Blackfriars Theatre or at the Globe Theatre in and around 1607. The play was included in the First Folio published in 1623. Shakespeare's source for the play was "Life of Mark Antony" from Plutarch's The Lives of the Noble Grecians and Romans, translated by Sir Thomas North in 1579. The play sets at the time of the Roman Empire which is divided between three triumvirs or power officers, one of which is Antony. He rules over the East and spends all his time in Egyptian revelries. He lives a decadent life and has an affair with the country's beautiful queen, Cleopatra. Caesar condemns Antony for neglecting his duties as a statesman and military officer. Caesar believes Antony is effeminized by spending too much time in Egypt. Antony's deterioration of reason (a faculty of mind stereotypically associated with masculinity)and blindness at times of making indecisive decisions throughout the course of the play is directly linked with his spending time in Egypt. Thus, he raises a large army against Antony and sends his army and navy to Egypt. Antony, persuaded by Cleopatra, elects to fight Caesar at sea. He allows Cleopatra to command Egypt's ships despite Enobarbus' strong objection. At last, Antony's forces lose the battle and the nobleman loses everything he has because of his great love for the Egyptian queen. After Antony hears 
the false news about Cleopatra's death, he commands one of his attendants to end his life so he can join his queen in the afterlife. The attendant, however, kills himself instead. Antony then falls on his sword, but the wound does not kill him immediately. He is carried to Cleopatra's monument where the two lovers reunite shortly before he dies. Meanwhile, Caesar is planning to take Cleopatra to Rome as a testament to the might of his empire. Cleopatra learns about his plan and decides to end her life with the help of poisonous serpents. Caesar buries her next to the grave of her dear Antony.

In Antony and Cleopatra, a number of scenes point to the relationship between gender and race. In the play, gender hierarchy and racial hierarchy are intertwined and embedded in the love relationship between Antony and Cleopatra. This research argues that Antony represents the masculine West, while Cleopatra represents the exotic and feminine East. However, this chapter brings a counter argument to the conventional outlook that sees a fixed division between the exotic, sentimental Orient and the rational, masculine Occident. It argues that in Cleopatra's character these hierarchies are overturned and Shakespeare, rather than supporting or defending the fixed notions about the East and the West, seems to be questioning their fixed, essential nature.

The Orient and the Occident are Eurocentric constructions that create an arbitrary binary opposition between the Western world and the Eastern world. The EastWest dichotomy attributes specific characteristics to each group and takes various forms. For instance, the Orient is thought to be irrational, barbarous and uncivilized and the depiction of its women is eroticized. As Chandra Talpade Mohanty puts it, the Western discourses "produce a corresponding set of universal images of the 'third-world women', images like the veiled women, the powerful mother, the chaste virgin, the obedient wife, etc" (Mohanty, 1988,p.81).This dichotomy also subordinates the peoples of the Orient to the position of the Other, establishing the West as a superior power. Contrastingly, the Occident is thought to be rational and civilized and its women are depicted as obedient. This discrimination and prejudice can be found in various literary representations, putting the Occident in an unequal position of power, namely, higher than the Orient, in order to justify imperialism and colonialism as well as to institutionalize racism. In his ground-breaking book, Orientalism, (1978) Edward Said explains that the Orient is a European invention and has been one of Europe' smost ingrained and most recurring images of the Other(Said,1978, p.1). In addition, drawing upon Derrida's concept of supplementary, Said argues that the Orient has helped to define Europe (or the West) as its contrasting image, idea, personality and experience (Said,1978,pp.1-2). Said defines Orientalism as the West's patronizing representations of the Orient, namely, the peoples and societies who inhabit North Africa, West Asia, also labelled as "the Middle East"in the Eurocentric discourse, and Asia. According to Said, Orientalism (referred to as the Western scholarship about the Eastern world) is inseparably tied to the imperialist societies who produced it, which makes most Orientalist works inherently political and servile to power (Said,1978,p.12).

At a first glance, Antony and Cleopatra seems to fit into the dynamics of an Orientalist outlook, intertwining the implications of gender hierarchy with imperial hierarchy. The playrests on a dichotomy between the masculine West and the feminine East. The masculine Roman Empire, which is shown as logical and moral, is set against its feminized dominion Egypt, which is rendered sensual, luxurious, corrupt and effeminate. Therefore, the passionate love between Antony and Cleopatra conflates the dynamics of imperial hierarchy with gender hierarchy. The sexual conquest of Cleopatra by Antony symbolizes the domination of Egypt by Rome. However, this power inequality is not as stable as it may look, because Cleopatra is also known as a cunning and manipulative woman who seduces men for her political ends, an essential stereotype associated with women. This chapter studies the implications of these hierarchies within a historical context and shows how the play can be interpreted as a tale which complicates the accepted narrative and unsettles the dynamics between the East and the West.

Although Antony is representative of the Occident and Cleopatra of the Orient, gender and racial hierarchies are unsettled. Since Shakespeare depicts Cleopatra as a cunning woman who seduces the Roman triumvir and turns Antony to a threat to the patriarchal Roman Empire. Antony, the great Roman soldier, loses himself in this relationship to the point where he is reduced to a woman before Caesar and his comrades. In act 1 scene 1 , Antony shows his reluctance to hear Caesar's messenger out from Rome. By stating "[H]ere is my space," he clearly mentions that all he wants is to be in Egypt with his beloved Cleopatra (1.1.37). This carelessness towards his duties and willingness to spend time with Cleopatra - the Eastern queen who is always followed by ladies and eunuchs - is viewed as becoming feminized in the eyes of Caesar and other comrades. What can Antony's emasculation imply in terms of imperial hierarchy? Despite the fact that we have been presented with this fixed 
opposition between the Occident and the Orient, the dynamics of Said's Orientalism are not valid within the context of the sixteenth and seventeenth centuries, when England was not yet even an empire. Throughout the sixteenth and seventeenth centuries the Ottoman Empire was the dominant superpower, because it was culturally, militarily and economically more advanced than any European state. Its territories expanded throughout North Africa, the Mediterranean and Eastern Europe, controlling many of the trade routes of the East. Europe could not mount a response against this Islamic enemy, rather, individual Christian nations often found themselves entering commercial and military alliances with the Ottomans, and in these interactions European monarchs never considered or articulated projects for colonizing these people (Matar,1999,p.9). For this reason, the gendered pattern of representing cross-cultural interaction with non-European peoples which we frequently see in early modern literature does not have colonial implications within an Ottoman setting and should be interpreted with historical realities of the age which indicate Ottoman's superiority over Europe(Öktem,2013,p.3). It is not claimed that Cleopatra represents Turks or the Ottoman Empire, however, her character as a powerful woman, who overturns imperial and gender hierarchies, invokes and plays with European anxieties in regard to the rising power of Islam. Ottomans invaded and defeated the Mamluks and by 1517 Egypt already became an Ottoman Eyalet ${ }^{1}$ and remained as an Ottoman dominion governed from Istanbul until 1798(Smith, Little and Others2019).At the time Shakespeare was composing Antony and Cleopatra, Egypt was still an Ottoman province.

In this play Shakespeare looks back to the events which happened in the first century BC, and which had been repeatedly narrated by Roman and other storytellers from that time to his own. From the very early ages of history this division between the East and the West existed. Since antiquity, the West always depicted the East as its inferior and associated feminine features with the East. The comparison between Plutarch's and Shakespeare's descriptions of Cleopatra's entry to Tarsus would be a good way to demonstrate how a certain European vocabulary in representing the Orient was created and inherited throughout centuries(Loomba,2002,p.112).In Act 2 Scene 2, the entrance

\footnotetext{
${ }^{1}$ Eyalet was a primary administrative division of the Ottoman Empire.
}

of Cleopatra is depicted in an exotic manner, which seems to fit into Said's Orientalism.

ENOBARBUS: I will tell you.

The barge she sat in like a burnished throne

Burned on the water. The poop was beaten gold,

Purple the sails, and so perfumed that

The winds were lovesick with them. The oars were silver,

Which to the tune of flutes kept stroke, and made

The water which they beat to follow faster,

As amorous of their strokes. For her own person,

It beggared all description: she did lie

In her pavilion - cloth-of-gold, of tissue-

O'erpicturing that Venus where we see

The fancy outwork nature. On each side her

Stood pretty dimpled boys, like smiling Cupids,

With divers-colored fans, whose wind did seem

To glow the delicate cheeks which they did cool,

And what they undid did. (2.2.226-242)

The barge like a throne, the perfume in the air, the silver oars, the cupid-like boys around the Egyptian queen are all associated with the exotic Orient. Through hyperbole, they all seem attractive, striking, colourful and at the same time unusual to Enobarbus. This vividly shows how the West sees the Orient. Cleopatra's beauty is indescribable. She is compared to images of the goddess Venus and is seen as even more beautiful than the idealized depictions of the goddess. In fact, she is turned into an imaginary character that permits fantasies of sexual desire and exudes romance, offering the pleasures of seduction. What has happened here is that Enobarbus has projected his own fantasies about and image of the East on to Cleopatra and her surroundings.

We can compare Enorbarbus's description with that of Plutarch:

She received several letters, both from Antony and from his friends, to summon her, but she took no account of these orders; and at last, as if in mockery of them, she came sailing up the river Cydnus, in a barge with gilded stern and outspread sails of purple, while oars of silver beat time to the music of flutes and fifes and harps. She herself lay all along under a canopy of cloth of gold, dressed as Venus in a picture, and beautiful young boys, like painted Cupids, stood on each side to fan her. Her maids were dressed like sea nymphs and graces, some steering at the rudder, some working at the ropes. The perfumes diffused themselves from the vessel 
to the shore, which was covered with multitudes, part following the galley up the river on either bank, part running out of the city to see the sight. The market-place was quite emptied, and Antony at last was left alone sitting upon the tribunal; while the word went through all the multitude, that Venus was come to feast with Bacchus, for the common good of Asia. (5:178-179)

In these two texts both Plutarch and Shakespeare render the East,"Asia," as exotic, feminine and/or effeminate (Venus,maid, nymph and the beautiful young boys) and sensual. This opposition between the East and the West becomes the fabric of other scenes as well. This way of depicting the Orient is the general structure of the East-West relationship and the two writers show this division clearly. Antony, an honorable Roman hero known for his war triumphs, is attracted to Cleopatra, the Egyptian queen. She shows herself as a desirable object to seduce men and this attractiveness poses a danger for the Roman Empire. Nonetheless, Western desire for Eastern riches is not hidden from our eyes. When the crowds come out to see Cleopatra, Antony is left alone waiting for her in the market place. Enorbarbus continues:

Upon her landing Antony sent to her,

Invited her to supper. She replied

It should be better he became her guest,

Which she entreated. Our courteous Antony,

Whom ne'er the word of "No" woman heard speak,

Being barbered ten times o'er, goes to the feast,

And for his ordinary pays his heart

For what his eyes eat only.(2.2.225-232)

When in Rome, Cleopatra rejects Antony's invitation to supper and replaces it with one of her own, and this is when she defies his will proving her resistance to any submission. Enobarbus explains "courteous Antony" who has never heard "No" from any woman, after being groomed ten times bythe barber, goes to the feast and yet only his eyes were satisfied. Cleopatra's cunningness and ambition are evident here. She makes a desirable attractive object out of herself but by replacing Antony's invitation to supper tries to practice her power and influence over him (the West).In so doing, she foreshadows her eventual domination of Antony(Belsey, 1985,p.41).Later in the play Cleopatra's power over the Roman triumvir will become a material threat to the Roman patriarchal order.

Cleopatra displays so many varieties, colors and moods. She is portrayed as a professional actress who knows how to exploit anyone to achieve her ambitious goals. She has an artistic temperament and consciously plays with Antony by constantly changing her mood which is a strategy to persuade him into doing what she likes. Upon hearing Antony's departure for Rome, Enobarbus remarks Cleopatra's possible reaction in such situations:

Cleopatra, catching but the least noise of this, dies instantly. I have seen her die twenty times upon far poorer moment. I do think there is mettle in death, which commits some loving act upon her, she hath such a celerity in dying. (1.2.152-160)

He admits that if Cleopatra hears even a breath of this, she would die immediately and that he has seen her dying twenty times for far more unimportant news. He assumes there has got to be something invigorating about death since she dies with such enthusiasm. By implication, she is likened to a mythological figure, Phoenix, with extraordinary power of endless cycles of resurrection, which also points to her fertile reproduction ability. Antony answers: "She is cunning past man's thought" (1.2.161). Then, Enobarbus sarcastically replies, "Alas, sir, no, her feelings come from pure love, not cleverness. Her sighs and tears are like great winds and floods. She has more storms and tempests in her than a weather almanac. Her temper is not a trick or a skill-if it is, she can make it rain as well as Jove" (1.2.162-167). Enobarbus' likening Cleopatra to Venus - capable of creating "storms and tempests" - still continues.

Cleopatra is also likened to an appetizer and dish, referred to as "salt Cleopatra" and "Egyptian dish" (2.6. 126), a "morsel" left on Caesar's plate (3.13. 117), a metaphor for her arousing desires among men towards her. However, she does not remain a delicious treat for the Romans, as she makes men "hungry where most she satisfies" (2.3. 279).

Enobarbus: Never. He will no.

Age cannot wither her, nor custom stale

Her infinite variety. Other women cloy

The appetites they feed, but she makes hungry

Where most she satisfies. For vilest things

Becomes themselves in her, that the holy priests

Bless her when she is riggish. (2. 2. 239-245)

Enobarbus does not believe that Antony would ever leave Cleopatra. He cannot help but saying how her varied charms never get boring. He thinks the more you get to know a woman, the less appealing she becomes. Instead, the more you see Cleopatra the more she makes you desire her. Even her worst faults are so charming that holy priests bless her even when she acts wanton. Her seduction is so powerful that 
she can overturn the patriarchal order. The fact that Cleopatra (Eastern queen) exercises her power over Antony (Western male triumvir) by cancelling his invitation to supper and replacing her own is an example of overturning patriarchal order. Cleopatra is very ambitious and seductive; her changing mood and mercurial nature are her tactics to seduce Antony and have him under her control in order to make him do what she wants. In other words, she has a plan and plot to fulfil her wish. Doing so requires intention and contemplation and is an exercise of the intellect as well as reason rather than the flesh or body with which women were stereotypically associated. For instance, in Act 1 Scene 3, she sends Alexas to report on what Antony is doing:

See where he is, who's with him, what he does.

I did not send you. If you find him sad,

Say I am dancing; if in mirth, report

That I am sudden sick. Quick, and return. (1.3.3-6)

As Belsey points out, seduction is more exciting

than sex (Belsey,1985, p.38). She continues that Shakespeare's Cleopatra "is shown consistently exploiting the lack which is the cause of desire" (Belsey,1985, p.41). An aspect of Cleopatra's playfulness is to make others want or imagine her while she is absent. Then, it is neither her beauty nor her presence that makes one hungry, but it is rather her promised presence that makes one most hungry. Cleopatra does tempt Antony by playing tricks upon him. She does not easily give herself to Antony but instead makes him desire her.In addition, seduction is more inventive and more subtle and requires wit as well as creativity. That is why she personally does not go after Antony; instead she sends Alexas to check upon him and by giving antithesis news to Antony makes him go after Cleopatra. Cleopatra is aware of what she is doing; she deliberately deceives Antony with her tricks and acts out by constantly changing her mood. Charmian warns her that she is not using the best way to get him to reciprocate. Instead, she asks Cleopatra to honestly show her love to Antony without acting, yet, Cleopatra answers: "Thou teachest like a fool: the way to lose him" (1.3.12). She actively exercises her agency by drawing on her intellect and innovation in a seductive, cunning way.

During the sixteenth and seventeenth centuries when the Ottoman Empire was the dominant power, English travellers, sailors and pirates would leave their countries in order to wander in Muslim lands or join the Ottoman navy because of the good employment opportunities and benefits offered to them by the Ottomans (Matar,1999,p.45).Many of these people converted to Islam in order to enjoy liberty and wealth under the Ottoman flag. In addition, tradesmen and other people who sought a better life settled in the Ottoman lands(Matar,1999,p.44).A parallel is created between England and Ottoman of Shakespeare's time and Rome and Egypt of the play. In the play, Egypt represents the East. Antony, the Roman soldier, is willing to leave his land and settle in the East as he finds Egypt more desirable than his home country. In Act 1 Scene 1, when Cleopatra urges him to hear out the messenger from Rome, Antony says: "Let Rome in Tiber melt and the wide arch / Of the ranged empire fall. Here is my space" (1.1.34-35). He finds staying in Egypt and spending time with his lover as the noble thing to do because he is satisfied in the East.In Act 2 Scene 3, the soothsayer reminds Antony that he has no chance against Caesar and he will lose in any game with him. The soothsayer says: "and of that natural luck / He beats thee "gainst the odds" (2.3.31-32).After the soothsayer leaves, Antony thinks to go back to Egypt. Though he marries Caesar's sister to make peace he says: "I' 'the East my pleasure lies" (2.3.46).East (as represented by Egypt) is a place of fulfillment of desires and sensual pleasure.

According to Richard Knolles, a famous historian whose books on the Ottomans and Eastern empires were very popular at Shakespeare's time, Egyptian women always chose their own husbands (Knolles, 1603, qtd. in Loomba,2002, p.119). It is not surprising that, as Belsey comments, Cleopatra competes with Antony's wives, without any sense of guilt or respect to their marriages. The play's Orientalism locates the East beyond the reach of law, a realm of pleasure where everything is permitted, where women openly talk about sex (as Cleopatra and her eunuchs do when they wait for Antony in Act 1 Scene 5). Unlike decent Octavia,who is shown as a naïve simple woman with a noble disposition and who tries to makepeace between her brother and husband, Cleopatra is a complicated character. She knows what she wants and intends to get it despite all the odds. After all, she is an Egyptian woman, free to choose her man and free to discuss what she likes. The moral contrast between Cleopatra can be clearly seen in the depiction of Roman ideals through the role of Octavia and that ofthe foreign queen Cleopatra, who opposes them. Octavia is said to be virtuous with graces that reveal her like no other woman by Agrippa. Octavia does not choose her husband but rather is chosen as bond between Antony and Caesar to make them cope with one another.Cleopatra deliberately separates as well as differentiates herself from Octavia and Rome with her political power and behaviour as a woman. As a rebellious and independent woman from the Orient, she represents the Other. In this case, Octavia embodies the 
characteristics of an appropriate Roman wife, such as wisdom, beauty and more importantly obedience to her husband. This illustrates a division between a world that is governed by reason, discipline and prudence on the one hand and passion, pleasure and love on the other. In Act 1 Scene 1 where Philo refers to Cleopatra as "[T]awny front" and "gipsy," he points out racial and cultural positioning, that refers to features attributed to the Orient(1.1.6-10). Philo compares Cleopatra to a gypsy. Gypsies, originally from Northern India, immigrated to Western Europe, from there to Scotland and arrived in England in early sixteenth century. In early modern England, gypsies were mistakenly thought to have come from $\operatorname{Egypt}($ Cressy, 2016, p.48).It is known that during the seventeenth century when Shakespeare wrote this play, Egyptians were mistaken with gypsies(Loomba,2002,p.115). Philo's comment on Cleopatra obviously shows the racial positioning that the queen of Egypt is on the same level as a gypsy and inferior to the Romans for the latter is white and racially superior. In the same era in which Antony and Cleopatra was written, the authorities did not like gypsies because they found it difficult to govern them and also because gypsies formed tight communities with their own hierarchies. Some of these gypsies were also dressing like Egyptian kings and queens (Loomba, 2002,p.130). Similarly, Cleopatra - who is likened to a gypsy by Philoin the play- is threatening to Rome because she is not just Antony's "Egyptian wife" but a sovereign who resists Egyptian's incorporation into the Roman Empire. She stands up for her sovereignty and Egypt's independence even though they are under the Roman reign. Therefore, Octavia is Rome (the Occident) and this allows Cleopatra to be shown as the opposite to the Roman ideal woman and highlights her Otherness.

Philo is evidently enraged by the fact that Antony fell for the queen of Egypt and he calls her a whore:

Look where they come.

Take but good note, and you shall see in him

The triple pillar of the world transformed

Into a strumpet's fool. Behold and see. (1.1.11-4).

Here, Philo draws Demetrius's attention to the fact that Antony, one of the three men who rule the world, has turned into "a strumpet's fool." He sees her as inferior to the Romans and believes that Antony has been downgraded because he is now spending his time in Egypt with his queen. Obviously, according to the sixteenth and seventeenth century world view in England, as elaborated by E. M. W. Tillyard in The Elizabethan World Picture, which functioned based on the concept of the Great Chain of Being, a system of hierarchy and order, someone who is brought down by choosing inferior companions has subverted and reversed the order and is consequently doomed to face a tragic end.

Gender reversal, as well as imperial overturn, is central in the play Antony and Cleopatra. As an Egyptian queen, Cleopatra represents the Orient and all its associations; Philo thinks that Antony's relationship with her is corruptive as he is submissive to her:

Nay, but this dotage of our general's

O'erflows the measure. Those his goodly eyes,

That o'er the files and musters of the war

Have glowed like plated Mars, now bend, now turn

The office and devotion of their view

Upon a tawny front. His captain's heart,

Which in the scuffles of great fights hath burst

The buckles on his breast, reneges all temper

And is become the bellows and the fan

To cool a gypsy's lust. (1.1.1-10)

Antony who used to look at his troops with such pride that his heart used to burst the buckles on his breastplate in great fights has now devoted his eyes to a darkskinned gypsy and has dedicated all his temperance and heart "[T]o cool a gypsy's lust" (1.1.1-10). Philo describes her "tawny front" and addresses her as "gypsy" but despite such racial implications and prejudices, Antony seems totally overpowered by this "gypsy". Therefore, it is Antony, rather than Cleopatra, who is portrayed as the submissive.

Similarly, in the opening of Act 1 Scene 4 we see Caesar commenting that Antony's revelry in Egypt has effeminized him:

From Alexandria

This is the news: he fishes, drinks, and wastes The lamps of night in revel, is not more manlike Than Cleopatra, nor the queen of Ptolemy More womanly than he; hardly gave audience, or Vouchsafed to think he had partners. (1.4.3-9)

Antony's choice of living a luxurious life in Egypt and spending time in revelries makes him effeminate in the eyes of Caesar. When Caesar receives the news that Antony fishes, drinks and celebrates every night, to him Antony becomes as frivolous and self-indulgent as Ptolemy's queen, Cleopatra. It seems that Antony barely acknowledges that he has allies and duties to care for. Clearly, in Caesar's eyes Antony has become womanish as he has gone to the East and has replaced his duties to Rome with lustful pleasures. Feasting, fishing and drinking are seen as waste fulina 
Roman's eyes.To him, Antony is seduced by this luxurious lifestyle. Antony's lifestyle in the Orient is based on fantasy, romance and revelry, and these liberate him from prudence and his duties as a Roman. He prefers to settle in Egypt in order to spend his time with his lover (queen of Egypt). He enjoys feasting and romancing with Cleopatra instead of taking care of his marshal duties. A Roman triumvir is expected to be focused on his responsibilities and nothing should be able to stop or distract him. Antony's way of life going native - destined him to fail in the eyes of the West. Similar to Romans in first century BC, the English authorities during the Renaissance feared their people going native, which is why the dreadful fate of going native became the subject of some literary works such as this play. The purpose of such writings was to warn people of the dangers of settling in Eastern lands and going native.

During the age of exploration, colonists, pirates and traders travelled across the globe - to the New World in the West and tothe Mediterranean and the Indies in the East - to seek materials and resources. Although, their position in North America was superior, their situation in the East, specifically in the Mediterranean, was the opposite. When planters were struggling in the wilderness of North America, their fellow citizens were pursuing fortunes along the coasts of North Africa (Barbary) and at the ports of the Ottoman Levant. While Europeans could claim colonial superiority in the New World, they were not able to have any colonial pretensions in Anatolia,Levant and North Africa, which were dominated by the Ottoman Empire (Vitkus,2003, p.30). Many Englishmen who sought a better lifesettled in the Ottoman lands to pursue their careers. English authorities feared that the awe-inspiring wealth and fascinating might of the Ottoman Empire might attract more and more Englishmen (Loomba, 2002, p.118).Also, pirates, sailors, merchants as well as captives who travelled or were taken to the Ottoman lands and settled there converted to Islam(turned Turk) or went native in order to enjoy the freedom and wealth offered to the renegades under Ottoman rule. To go native means to desert one's own way of living by settling down in a new place (country) and adopting their lifestyle which is different than one's country of origin (Macmillan Dictionary 2020).Linda Colley, in "Going Native, Telling Tales: Captivity, Collaborations and Empire" (2000), gives accounts of British captives in who turned native and argues they became a source of anxiety,"of fears of a militant dangerous Islam" (p. 188). She also speaks of the role reversal that happened in slave markets of the Ottoman Empire where "white as well as black captives might be stripped and exhibited, before being sold into servitude of different kinds" (p. 177). Although Colley's focus is mainly the Seventeenth and Eighteenth centuries, the fear and anxiety of going native expressed earlier in literary writings.

From the European perspective, these men who adopted Eastern life style were unmanned since they became circumcised and/or chose exotic and sensual way of living. Similarly, Antony has given himself excessively to an Eastern woman who anchors him to a new cultural identity and lays him exposed to charges of unmanliness. Antony's passions put him in a dilemma between his Roman martial self and his new Egyptian or Oriental identity. Cleopatra's followers are either women or eunuchs, and Antony whose lustful, pleasure-seeking life style has turned him unmanned joins them too. Therefore, the story of Antony and Cleopatra can be understood as a cautionary tale, a story that warns Westerners about the dangers of the East. Since the powerful markets of Asia and North Africa were both desired and feared, we can understand the necessity of this story to warn of the dangers of going native. Similarly, "going native" was used in the New World context and it meant to become like indigenous people. This was assign of the loss of identity and becoming the other. Consequently, although Antony did not desert his faith it can be detected in Antony's chosen way of living that he goes native. He not only went native by living an Egyptian way of life but also betrayed Rome by turning his back on his duties toward them. For example, he spends much of his time drinking, fishing and feasting in Egypt rather than caring for his responsibilities in Rome. In addition, he becomes irrational by being obedient to Cleopatra contrary to Roman customs according to which men are to be the patrons while women are expected to be silent and obedient. By depicting Antony"going native,"Shakespeare brings back the fears of conversion associated with Eastern empires and other non-European communities with which the English were in contact.

Moreover, Cleopatra herself seems to be aware that she overturns gender hierarchies. In Act 2 Scene 1, wondering how she would pass time until her lover's return to Egypt, Cleopatra imagines herself fishing by the River Nile and likens Antony to the fish that she might catch:

My bended hook shall pierce

Their slimy jaws, and as I draw them up

I'll think them every one an Antony

And say “Aha! You're caught." (2.5.14-7)

This reminds us that Cleopatra is not Antony's Egyptian conquest. She, herself, intentionally overturns the gender 
imbalance between them. Thanks to her seductiveness, every man for her is like a fish on the hook. Moreover, she is aware that her power over Antony effeminizes him. She recalls that one morningshe had Antony so drunk and made him wear her dress while she wore his sword:

I drunk him to his bed,

Then put my tires and mantles on him, whilst

I wore his sword Philippan. (2.5.25-7)

Thus, Cleopatra overturns not only gender hierarchies but also imperial hierarchies. A sword symbolizes masculinity and is obviously very important to a soldier. Loomba expresses that such cross dressing is not just bedroom play but manifests a larger reversal of gender roles(Loomba,2002, p.120). By effeminizing him, Cleopatra threatens both racial and imperial hierarchies between imperial Rome and Egypt: a horrific possibility of turning the West effeminate and submissive.

In addition, Cleopatra persuades Antony to fight the Romans at sea rather than on land, a decision that is seen unman not just to Antony but all his Roman soldiers. Antony knew he would certainly have had the upper hand in the battleif he fights on land and so do his troops but at last, he decides to fight at sea because of Cleopatra's persuasiveness. The fact that Antony prefers Cleopatra's saying over his troops based upon facts unmans Antony as well as his soldiers. Enobarbus pleads with Antony: "Transform us not to women" (4.2.47) and Camidius mourns: 'So our leader's led / And we are women's men' (3.7.86-7). Thus, these gender, patriarchal and racial reversals make it difficult to represent the colonized land, as embodied in Egypt, as a sexually available female. She is a royal woman and does not give her sovereignty up easily.

In the battle of Caesar against Antony, when Cleopatra decides to join her shipsto his fleet, Enobarbus goes against this decision. He believes her presence is going to distract Antony as she brings turmoil to his heart and mind. Consequently, this confusion causes him to lose the battle. Regardless of Enobarbus' words she decides to join the battle as the war is against Egypt.Antony, persuaded by Cleopatra, orders his troops to hold back the attack until the sea battle is over. Shortly after the battle begun, Enobarbus cries: "Naught, naught, all naught! I can behold no longer. [T]h' Antoniad, the Egyptian admiral, [W]ith all their sixty, fly and turn the rudder.To see 't mine eyes are blasted" (3.10.1-4). He describes that he witnessed the Egyptian flagship, Antony and all other Egyptian ships turn and flee the battle. This action confuses the fleet and accordingly the victory goes to Caesar. Antony's soldiers are sickened by the sight. Scarus states that when Cleopatra turns around, noble Antony ruined by love follows her like a sick mallard. For this reason, Camidius deserts Antony but Enobarbus, despite all the odds, remains loyal to his general. Deeply ashamed of his performance in the battle, Antony urges his servants to desert him as he has already deserted his own noble ideals.Antony lost his reputation, power and manliness to Cleopatra (or Egypt), by following her. Now, when he looks back, he sees himself destroyed by dishonour. He asks Cleopatra why she has led him into infamy, she begs for forgiveness saying: "I little thought you would have followed" (3.11.54-5). He then asks how she could doubt that he would follow her as his heart is tied to her (strongly showing Antony's submission is to Cleopatra rather than the other way around).Then, Cleopatra uses her tricks to rise Antony's pity and cries and begs for forgiveness; Antony asks her not to shed any tears as even one drop is equal to all that he has won and lost. He asks for a kiss, saying "even this repays me" (3.11.70). This scene clearly depicts Antony subdues to Cleopatra (representative of the East) and gives his everything for only a kiss from his Eastern lover. Antony lost an almost equal battle against Caesar only because he decides to retreat and follow Cleopatra's ships which fled from the battle. According to patriarchal norms and in Roman eyes a man who is blinded by his emotions towards a woman, subdues to her and forgets all his power, territories as well as his reputation in battle with only a kiss from his lover is unmanned.

Enobarbus tells Cleopatra all that has happened is Antony's fault not hers since Antony had the liberty to follow logic rather than lust. The fact that not only Antony's heart but his whole being is conquered by Cleopatra is evident in the scene of the battle. By overturning both gender and patriarchal hierarchies, Cleopatra has made her lover submit to her. She is involved in any decision making and her words are the dominant opinions between the two lovers. Later on, Antony's ambassador arrives at Caesar's to deliver his and Cleopatra's messages. Caesar carelessly dismisses Antony's request but declares that Cleopatra shall get what she wants so long as she either throws her dishonoured lover out of Egypt or kills him there. After Antony receives Caesar's answer, he becomes furious and challenges Caesar to one-on-one combat. Enobarbus observes everything and yet decides to remain loyal to his master. Even though his integrity is in conflict with his self, he thinks staying loyal to a defeated lord defeats his lord's conqueror and earns him a place in history. Meanwhile, Thidias comes to tell Cleopatra that if she relinquishes custody of Antony, Caesar will show 
her mercy. The queen admits that she embraced Antony out of fear rather than love. Just then, Antony enters in fury and demands Thidias be whipped and protests against her queen's betrayal of Antony. Cleopatra however, protests that she would never betray him, and this is enough to satisfy Antony. While observing this scene, Enobarbus thinks he has been faithful to his master long enough. He feels that Antony's mind is slipping, and that it is the time for him to abandon his master. Initially masculine Roman Antony listens to Cleopatra and acts according to her will, which is why he, for instance, loses the battle at the sea. Although Antony knew he definitely could defeat Caesar on land, he was easily convinced by Cleopatra to fight at sea. Thus, this decision failed Antony and enraged his soldiers. Accordingly, the fact that these hierarchies are not stable deserves attention.

What is the implication of Cleopatra's cunningness and overturning of patriarchal hierarchies in terms of the play's historical context? These gender and imperial reversals might allude to the political dynamics of the late sixteenth and early seventeenth century. In early modern England, Egypt was known for its ancient religion and philosophy, as well as being the sourceof mummy trade. Meanwhile, Egypt was also becoming more and more identified as a Turkish dominion as it had been part of the Ottoman Empire since 1516, governed by Turkish Sultans, who were Muslims.

In both New World narratives and representations of contact with Eastern people, it is almost always European men who, with their virile masculine virtue and attractiveness, steal the heart and body of non-European women and make them leave their own "uncivilized" culture to elope with the European man. Julius Caesar was in relationship with both Cleopatra and Eunoe (wife of King Bogudes), Alexander the Great (Alexander III of Macedon) married to Roxana (daughter of Persian king). These men, however, did not allow their relationships to distract them from their missions (Loomba, 2002, p.116-17)."Imperial conquest" is often shown through the "sexual possession" of "conquered women" (Loomba, 2002,p.116). In Antony and Cleopatra instead of a European converting an Eastern queen, we see the Egyptian queen make Antony abandon himself. Since Antony loses his way in the Orient, he completely forgets his duties. He, inevitably, has to go back to Rome to conduct his affairs but he constantly returns to Egypt (Cleopatra). Thus, his association with Cleopatra, by contrast, reverses sexual, gender and imperial dynamics which signifies not his victory but hers(Loomba, 2002,p.116-
17). Cleopatra not only does not allow herself to be conquered by Antony, but she does everything to claim her sovereignty and to make the Ptolemy dynasty remain in power. Likewise, her dominant personality and her overturning of gender and power hierarchies can be seen as her success in achieving what she desires. By conquering Antony, Cleopatra reverses the common image of conquering male and conquered female.

This conquest also has clear political implications. Antony gives the rule of Egypt to Cleopatra and makes her the absolute queen of lower Syria, Cyprus and Lydia. After, in the public arena, he proclaims his sons to be kings among kings. He gives great Media, Parthia and Armenia to Alexander. He also assigns Syria, Cilicia and Phoenicia to Ptolemy. This act enrages Caesar as he believes himself to have a share in those territories. Eventually, Antony sends Octavia to her brother and uses the opportunity to reunite with his lover, Cleopatra. Caesar learns of this when his sister comes to him in silence without any attendants. He consequently becomes furious and orders to prepare his army to attack Antony without a moment of hesitation. The fact that Antony gives out territories to the Ptolemy poses danger to the Roman Empire. Antony's sending Octavia back in order to reunite with his Egyptian queen enrages Caesar provoking him to raid Egypt. The imperial hierarchy is overturned and there is even the danger of being attacked by the Ptolemy queen. This incident terrifies the Roman Empire in the same manner as Europe was terrified by the fact that they were losing territories to the powerful Ottoman Empire during the sixteenth and seventeenth centuries.

In Antony and Cleopatra, Antony's fatal attraction to Cleopatra speaks to contemporary English fears about the erosion of identity and masculinity (Loomba, 2002, p.133). This noble Roman soldier willingly accepts his defeat out of the great love he has for Cleopatra. Despite all his famed strength and courage, he has flaws as well as any other human being. His flaw is undoubtedly going native and leaving his world behind. Given the many works written by English authors and sermons given by the church and reactions of the crown against feminization, "turning Turk" and "going native" prove the fears of the English authorities and the public towards the dominating East. Cleopatra's love for Antony does not mean that she submits to Rome. She plays with different personas in order to control Antony. Her character there for reinforces English concerns about the feminization of Englishmen in their encounters and lustful relationships with sexually profligate Muslim temptresses(Burton, 2005,p.26-7). 
Cleopatra is uncontrollable, slippery, unpredictable and probably the most seductive amongst Shakespeare's female figures. She is a cunning and beautiful mistress of changing moods and disguises and a master of mystery. She does not submit to either Antony or Caesar which is why in the end when she loses all her power, she writes the final script by designing her own death instead of being taken to Rome as testament to and proof of Caesar's power. Even her actual death scene conjures seduction in the mind of the reader. As Caesar watches her body and exclaims:

She looks like asleep,

As she would catch another Antony

In her strong toil of grace.(5.2.415-17)

She does not seem dead;it is as if she has fallen asleep. Caesar's way of describing her suggests the idea of Cleopatra acting in order to deceive another Antony. In other words, it is not her presence nor simply her absence that is seductive, but her imagined, promised presence.

The overturning of gender hierarchy and power hierarchy through cross-dressing and manipulation that the play presents are proof of the West's fear regarding identity exchange, that Englishmen might go native or likewise lose their identity during overseas contacts. As a result, perhaps this depiction of Cleopatra by Shakespeare can be seen as a warning against the danger that threatens Englishmen. She is in fact the embodiment of the East, which is not only sensual but also clever, seductive and confident; even so, her charisma, strength and unconquerable personality make her one of the most awe-inspiring characters of Shakespearian drama.

Despite the English incursions into the Eastern world as depicted in many Renaissance English works of the late sixteenth and early seventeenth centuries in order to demonize the world of Islam and Eastern powers, their interactions did not imply any pattern of English domination or superiority. Said, as his critics say, is attributing a colonial vision of the East to pre-colonial times. During the Renaissance, the East could hardly be regarded as Europe's other. Europeans sought ways to enter into the powerful economic networks of the Mediterranean, Levant, North Africa and Asia, feared the military might of the Turks and were dazzled by the wealth and sophistication of many Eastern kingdoms. In fact, Europe was really on the periphery of powerful economic networks whose centre was in the East and that European global domination did not begin until the eighteenth century (Loomba, 2002,p.117-18).

\section{REFERENCES}

[1] Belsey, C1985,"Cleopatra's Seduction," in Hawkens T (ed.),Alternative Shakespeares, Vol. 2, Psychology Press, Routledge, pp. 38-62.

[2] Burton, J 2005,Traffic and Turning Turk, University of Delaware Press, Newark.

[3] Cressy D 2016, 'Trouble with gypsies in early modern England', The Historical Journal, vol. 59, no. 1, pp. 45-70, viewed $24 \quad$ December 2019, <https://doi.org/10.1017/S0018246X15000278>.

[4] Colley, L 2000, 'Going Natives, Telling Tales: Captivity, Collaborations and Empire',Past \& Present, No. 168, pp. 170193, viewed 27 December $2019,<$ https://www.jstor.org/stable/651308>

[5] Loomba, A 2002,Shakespeare, Race, and Colonialism, Oxford University Press, Oxford.

[6] Macmillan Dictionary, 2020, viewed 5 January 2020, <https://www.macmillandictionary.com/dictionary/british/gonative $>$.

[7] Matar, N1999,Turks, Moors, and Englishmen in the Age of Discovery, Columbia UniversityPress, New York.

[8] Mohanty, CT 1988, 'Under Western Eyes: Feminist Scholarship and Colonial Discourses',Feminist Review, No. 30, pp. 61-68, viewed 7 January 2020, <https://www.jstor.org/stable/1395054>.

[9] Öktem, Ö 2013, 'Re-Orienting Gender and Islamic Alterity in Early Modern English Drama', Unpublished PhDthesis,Aristotle University of Thessaloniki.

[10] Plutarch, editor: Leo FA 1878, Four Chapters of North's Plutarch; Photolithographed in the Size of the Original Edition of 1595, Trubner, London.

[11] Said, EW 1978,Orientalism, Penguin Classics, London.

[12] Shakespeare, W 1606,Antony and Cleopatra,ICON Group International, California.

[13] Smith, CG \& Little, DP \& Others 2019, Egypt, Encyclopaedia Britannica, Inc., Encyclopaedia Britannica, viewed 23 December 2019, 〈https://www.britannica.com/place/Egypt>

[14] Tillyard, EMW 1998, The Elizabethan World Picture,London, Pimlico.

[15] Vitkus, DJ 2003,Turning Turk, Palgrave Macmillan, London. 